JURNAL TEEKROSAINS

VOLUME 4

No. 1, 22 Desember 2014

Halaman 1-102

\title{
MODEL KESUKSESAN PRODUK SANITER
}

\author{
Andrean Emaputra \\ Pascasarjana Teknik Industri Universitas Gadjah Mada \\ Email: a.emaputra@gmail.com \\ Subagyo \\ Jurusan Teknik Mesin dan Industri Universitas Gadjah Mada \\ Email: subagyo@ugm.ac.id
}

\begin{abstract}
A company that manufactures home decorations and sanitary products has not been able to achieve the expected production utility. This was indicated by the installed production capacity (of the sink) in 2013, which has not been completely consumed. Therefore, studies that explore customer needs and their corresponding levels of customer satisfaction need to be done. Achieving the desired product quality and customer satisfaction can be an entrance for achieving higher sales. This study was conducted in several stages, with the sink selected as the type of product for the research object. First, the quality attributes of the sink were identified. Second, the importance levels of the quality attributes were searched by questionnaires. Third, the sink quality attributes were grouped into the classification of quality attributes by the Kano model. This study gave some results. First, $90 \%$ of the average importance level of the sink quality attributes were between 'important' and 'extremely important'. Second, the survey that used the Kano model indicated that (1) 'performance' was a must-be quality attribute, (2) 'aesthetics' was not an indifferent quality attribute from 'attractiveness', except for 'excellence drainage', which was classified into a must-be quality attribute, (3) features could improve customer satisfaction quickly through 'the sink price is competitive', (4) the 'durable sink color' and 'scratch resistant' attributes can increase customer satisfaction, (5) 'materials that are for maintenance are included when buying the sink' could increase consumer satisfaction very quickly, and (6) the higher the reputation of the company, the higher the customer satisfaction.
\end{abstract}

Keywords: Product success, Kano model, Sanitary, Sink

\begin{abstract}
ABSTRAK
Suatu perusahaan yang memproduksi dekorasi rumah dan saniter belum dapat mencapai utilitas produksi yang diharapkan. Hal tersebut ditunjukkan dengan kapasitas produksi terpasang (dalam satuan wastafel) tahun 2013 yang belum terpakai seluruhnya. Oleh karena itu, penelitian yang menggali kebutuhan pelanggan beserta kepuasan pelanggan yang bersesuaian dengan pemenuhan kebutuhan pelanggan tersebut perlu untuk dikerjakan. 'mencapai kualitas produk yang diinginkan' dan 'kepuasan pelanggan' dapat menjadi pintu masuk tercapainya utilitas produksi yang tinggi. Penelitian ini dilaksanakan melalui beberapa tahap dengan jenis produk yang dipilih sebagai obyek penelitian adalah wastafel. Pertama, atribut kualitas wastafel diidentifikasi. Kedua, tingkat penting atribut kualitas wastafel tersebut dicari dengan kuesioner. Ketiga, atribut kualitas wastafel tersebut dikelompokkan ke dalam klasifikasi atribut kualitas model Kano. Penelitian ini memberikan beberapa hasil. Pertama, 90 \% atribut kualitas wastafel
\end{abstract}


memiliki tingkat penting rata-rata yang bernilai di antara 'penting' dan 'luar biasa penting.' Kedua, survei model Kano tersebut menunjukkan bahwa (1) kinerja tergolong must-be quality attributes, (2) Seluruh atribut kualitas dari estetika yang bukan indifferent quality attributes masuk ke dalam klasifikasi attractive quality attributes, kecuali drainase yang bagus masuk ke dalam must-be quality attributes, (3) fitur dapat meningkatkan kepuasan konsumen dengan cepat melalui ‘harga wastafel yang kompetitif,' (4) warna wastafel yang tahan lama dan wastafel yang tahan gores dapat menaikkan kepuasan pelanggan, (5) 'penyertaan bahan untuk perawatan saat pembelian' dapat meningkatkan kepuasan konsumen dengan sangat cepat, serta (6) semakin baik reputasi perusahaan maka kepuasan konsumen juga akan semakin baik.

Kata Kunci: Kesuksesan produk, Model Kano, Saniter, Wastafel.

\section{PENGANTAR}

Suatu perusahaan menghasilkan dekorasi rumah dan saniter. Produk-produk tersebut meliputi wastafel, patung, penyangga patung, pot, penyangga pot, meja, penyangga meja, air mancur, dan kotak surat.
Beberapa fakta yang terkait dengan kinerja perusahaan tersebut dapat dilihat pada Gambar 1. Pertama, jumlah pesanan barang mengalami kenaikan dari tahun 2004 sampai tahun 2006 dan mencapai puncaknya pada tahun 2006 (jumlah pesanan barang dinyatakan dalam satuan wastafel agar penggunaan kapasitas produksi dari tahun ke tahun dapat dibandingkan karena setiap jenis produk membutuhkan jumlah jam pembuatan yang berbeda). Kedua, jumlah penjualan barang perusahaan tersebut mengalami penurunan dari tahun 2006 ke tahun 2009 sampai di bawah kapasitas produksi terpasang tahun 2013. Ketiga, pada tahun 2010, jumlah penjualan barang perusahaan tersebut kembali naik dan dapat melebihi kapasitas produksi terpasang tahun 2013. Keempat, jumlah penjualan barang tahun 2010 yang melebihi kapasitas produksi terpasang tahun 2013 tersebut tidak berlanjut pada tahun-tahun berikutnya. Perusahaan tersebut terus mengalami penurunan jumlah barang yang dijual dari tahun 2010 sampai bulan Agustus 2014. Jumlah pesanan barang yang masih di bawah kapasitas

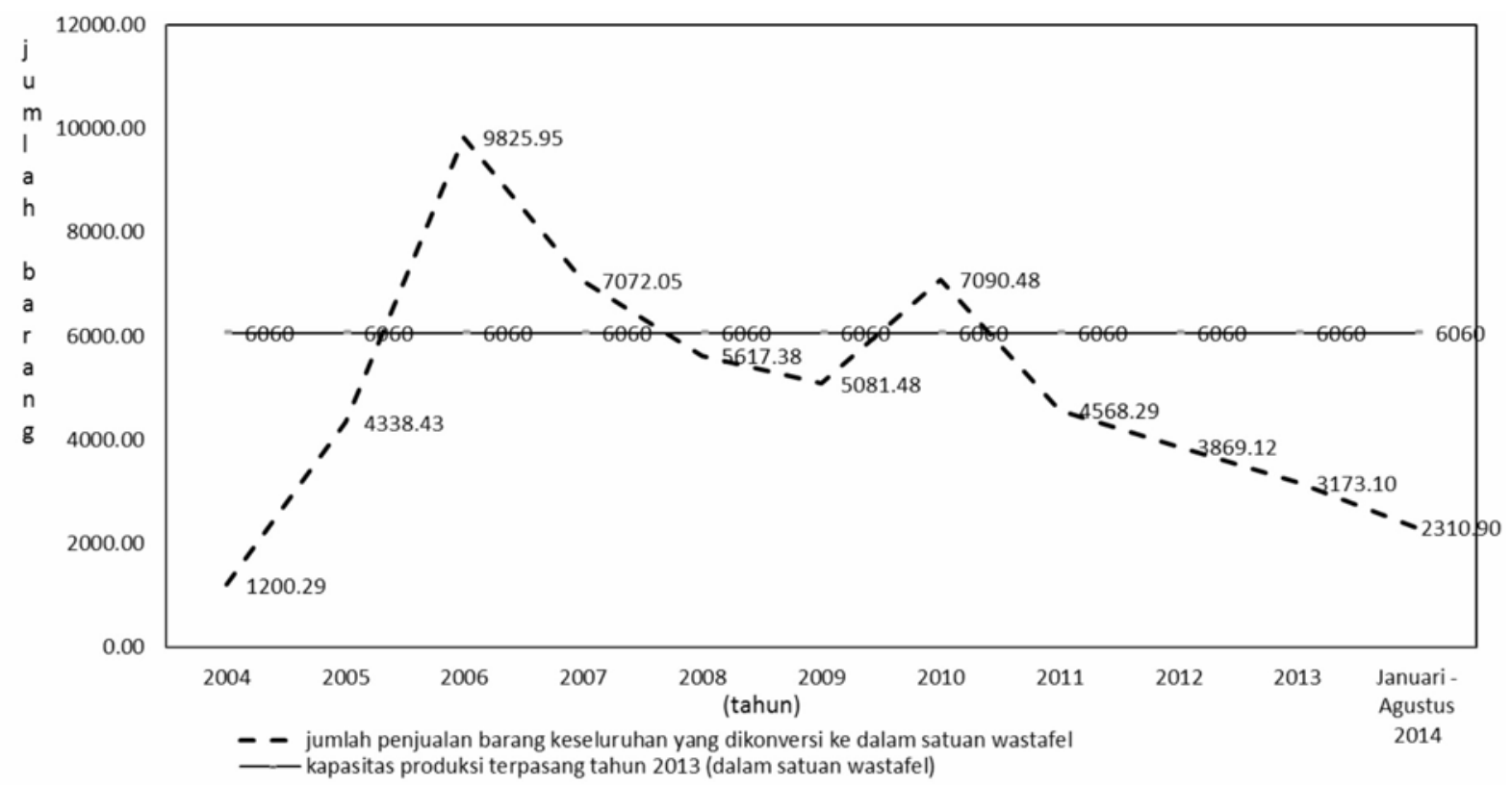

Gambar 1. Perbandingan Jumlah Penjualan Barang Keseluruhan dan Kapasitas Produksi Terpasang Tahun 2013

(dalam satuan wastafel) 
produksi terpasang tahun 2013 tersebut juga menunjukkan bahwa masih ada jam kerja yang masih sangat tersedia untuk menghasilkan produk-produk.

Utilitas produksi perusahaan tersebut yang mengalami penurunan dari tahun 2010 sampai Agustus 2014 dapat disebabkan sebagai berikut: (1) Atribut kualitas wastafel beserta tingkat pentingnya belum diketahui dengan baik oleh perusahaan tersebut pada konsumen Indonesia dan luar negeri. (2) Kebutuhan (calon) pelanggan yang berasal dari Eropa dan kawasan lain (Asia Tenggara, Asia Timur, Asia Selatan, Afrika, Amerika Selatan, Australia, Amerika Tengah, dan Asia Barat) beserta kepuasan konsumen yang bersesuaian dengan pemenuhan kebutuhan pelanggan tersebut belum diketahui dengan baik. (3) Kebutuhan (calon) pelanggan yang berasal dari Indonesia beserta tingkat kepuasan pelanggan yang bersesuaian dengan pemenuhan kebutuhan pelanggan tersebut belum diketahui dengan baik.

Jumlah penjualan barang yang di bawah kapasitas produksi terpasang tahun 2013 tersebut dapat menimbulkan beberapa dampak negatif. Pertama, pendapatan perusahaan menjadi berkurang karena produk yang dihasilkan oleh perusahaan tersebut juga berkurang. Kedua, perusahaan harus tetap membayar gaji karyawan dengan jumlah yang sama, sedangkan pendapatan perusahaan menurun. Ketiga, jika kondisi tersebut dibiarkan begitu saja, maka keberlangsungan hidup perusahaan dan pekerjaan para pekerja perusahaan tersebut juga dapat terancam.

Berdasarkan latar belakang tersebut, maka dapat dirumuskan permasalahan yang ada, yaitu utilitas produksi perusahaan tersebut mengalami penurunan dari tahun 2010 sampai Agustus 2014. Oleh karena itu, solusi untuk meningkatkan utilitas produksi tersebut perlu ditemukan dengan mengidentifikasi atribut kualitas wastafel dan tingkat pentingnya serta kebutuhan pelanggan-kepuasan pelanggan pada konsumen-konsumen tersebut.

Penelitian ini bertujuan untuk (1) Mengetahui atribut kualitas wastafel dan tingkat penting atribut kualitas tersebut; (2) Mengetahui kebutuhan (calon) pelanggan yang berasal dari Indonesia terhadap wastafel beserta kepuasan pemenuhan kebutuhan tersebut dengan mengelompokan atribut kualitas wastafel berdasarkan model Kano; dan (3) Mengetahui kebutuhan (calon) pelanggan yang berasal dari Eropa dan kawasan lain terhadap wastafel beserta kepuasan pemenuhan kebutuhan tersebut dengan mengelompokkan atribut kualitas wastafel berdasarkan model Kano.

Model Kanomemilikikelebihan.Pertama, model tersebut dapat menggambarkan pengaruh pemenuhan atribut kualitas (kebutuhan pelanggan) terhadap kepuasan pelanggan. Kedua, model Kano tersebut dapat menjadi pintu masuk untuk melakukan inovasi dengan adanya klasifikasi attractive quality attributes pada model Kano tersebut. Ketiga, model tersebut dapat menunjukkan perubahan kepuasan pelanggan, misalnya klasifikasi atribut kualitas tertentu berubah dari attractive quality attributes ke mustbe quality attributes, sehingga kepuasan konsumen juga berubah dengan pemenuhan kebutuhan yang sama.

Model Kano telah dipakai secara luas pada berbagai bidang untuk mengidentifikasi pengaruh kebutuhan pelanggan terhadap kepuasan pelanggan. Bidang-bidang tersebut dapat dilihat pada Tabel 1. Penelitian ini akan menggunakan model Kano untuk menunjukkan hubungan antara pemenuhan kebutuhan pelanggan dan kepuasan pelanggan pada wastafel.

Tabel 1. Bidang Penerapan Model Kano 


\begin{tabular}{l|l}
\hline \multicolumn{1}{c|}{$\begin{array}{c}\text { Bidang Penerapan } \\
\text { Model Kano }\end{array}$} & \multicolumn{1}{c}{ Peneliti } \\
\hline Saniter & Area penelitian ini \\
\hline Otomotif & $\begin{array}{l}\text { Xu dkk. (2009); Fariza (2011); Trisna (2013); Luthfitriaputri (2013); Yadav } \\
\text { dkk. (2013); Luthfitriaputri (2014) }\end{array}$ \\
\hline Elektronik & $\begin{array}{l}\text { Yang (2005); Wang dan Ji (2010); Ullah dan Tamaki (2011); Fariza (2011); } \\
\text { Yang dan Yang (2011); Trisna (2013); Luthfitriaputri (2013); Luthfitriaputri } \\
\text { (2014); Chang dan Chen (2014) }\end{array}$ \\
\hline Perhiasan & Bilgili dkk. (2011) \\
\hline Pendidikan (kampus) & $\begin{array}{l}\text { Garibay dkk. (2010); Li (2011); Rezaie dkk. (2012); Gruber dkk. (2012); } \\
\text { Lajevardi dkk. (2012); Liu (2013) }\end{array}$ \\
\hline Jaringan transportasi & Lai dan Wu (2011) \\
\hline Pariwisata & $\begin{array}{l}\text { Hogstrom dkk. (2010); Chang dan Chen (2011); Yang dkk. (2011); Erto dkk. } \\
\text { (2011); Chang dkk. (2012); Sukwadi dan Yang (2014) }\end{array}$ \\
\hline Agen perjalanan & Shahin (2004); Shahin dan Nekuie (2011) \\
\hline Industri café & Sukwadi dkk. (2012) \\
\hline Pangan & $\begin{array}{l}\text { Yooyen dan Leerattanakorn (2011); Chen (2012); Yu (2013); Cheng dkk. } \\
\text { (2013); Kuo dkk. (2014); Luthfitriaputri (2014) }\end{array}$ \\
\hline Bank & Chen dan Kuo (2011); Mikulic dan Prebezac (2011); Strandberg dkk. (2012) \\
\hline Perbelanjaan & Liu (2011); Kurt dan Atrek (2012); Oh dkk. (2012) \\
\hline Kesehatan & Cordero-Ampuero dkk. (2012); Matias-Guiu dkk. (2012); Nugroho (2013) \\
\hline Kemasan produk & Lofgren dkk. (2011) \\
\hline Perancangan website & Chaudha dkk. (2011) \\
\hline Pajak & Lin dkk. (2010) \\
\hline Pesawat terbang & Mikulic dan Prebezac (2011); Fariza (2011); Trisna (2013); Nugroho (2013) \\
\hline Perumahan & Llinares dan Page (2011) \\
\hline Pakaian & Bennur dan Jin (2013) \\
\hline Percetakan & Ghorabi dkk. (2012) \\
\hline &
\end{tabular}

Model Kano adalah model yang digunakan untuk menunjukkan kepuasan konsumen terhadap kinerja dari produk (barang/jasa) seperti dapat dilihat pada Gambar 2 (Lofgren dan Witell, 2005). Secara umum kategori atribut kualitas yang terdapat pada model Kano terdiri dari lima macam. Pertama, Jenis atribut kualitas model Kano adalah attractive quality attributes. Kano dkk. mengatakan bahwa atribut tersebut memberikan kepuasan saat dicapai kualitasnya, tetapi tidak mengakibatkan ketidakpuasan saat tidak dipenuhi persyaratannya (Lofgren dan Witell, 2005). Kehadiran atribut ini akan menimbulkan kepuasan konsumen yang luar biasa tinggi (Kaebernick dkk., 1996).

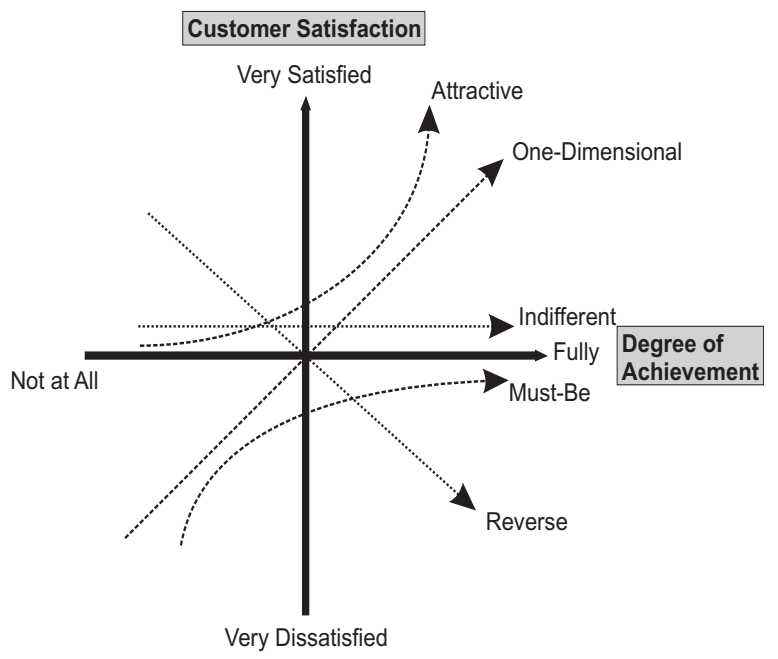

Gambar 2. Model Kano (Lofgren dan Witell, 2005) 
Kedua, Jenis atribut kualitas model Kano one-dimensional quality attributes. Kano dkk. mengatakan bahwa one-dimensional quality attributes menghasilkan kepuasan saat dipenuhi kebutuhannya dan menimbulkan ketidakpuasan saat tidak dipenuhi kebutuhannya (Lofgren dan Witell, 2005). Kaebernick dkk. (1996) menyebut one-dimensional quality attributes sebagai kualitas kinerja yang merupakan keinginan yang disampaikan, keinginan dasar, dan kebutuhan saat ini (Kaebernick dkk., 1996).

Ketiga, Jenis atribut kualitas model Kano must-be quality attributes. Kano dkk, memaparkan bahwa must-be quality attributes dianggap sebagai sesuatu yang semestinya didapatkan oleh pelanggan (Lofgren dan Witell, 2005). Atribut ini akan memberikan rasa netral kepada konsumen saat dipenuhi kebutuhannya, tetapi akan menghasilkan ketidakpuasan yang luar biasa saat tidak dipenuhi kebutuhannya (Kaebernick dkk., 1996; Lofgren dan Witell, 2005).

Keempat, Jenis atribut kualitas model Kano indifferent quality attributes. Indifferent quality adalah aspek-aspek yang tidak bagus dan tidak buruk, sehingga atribut jenis ini tidak menghasilkan kepuasan pelanggan dan ketidakpuasan konsumen (Lofgren dan Witell, 2005).

Kelima, Jenis atribut kualitas model Kano reverse quality attributes. Reverse quality adalah pemenuhan kebutuhan yang tinggi akan menghasilkan ketidakpuasan, sedangkan pemenuhan kebutuhan yang rendah akan menghasilkan kepuasan (Lofgren dan Witell, 2005).

Penentuan klasifikasi atribut kualitas model Kano dilakukan dengan kuesioner dan tabel evaluasi. Kuesioner digunakan untuk menggali kebutuhan pelanggan (Tabel 2), sedangkan tabel evaluasi digunakan untuk mengelompokkan atribut (Tabel 3).

Tabel 2. Contoh Kuesioner Model Kano

(Ullah dan Tamaki, 2010; Cordero-Ampuero dkk., 2012)

\begin{tabular}{l|l|l|l}
\hline \multicolumn{1}{c|}{ Deskripsi Atribut } & \multicolumn{1}{c|}{ Functional Answer } & \multicolumn{1}{c}{ Dysfunctional Answer } \\
\multirow{2}{*}{$\begin{array}{l}\text { The hospital is open } \\
\text { hours a day. }\end{array}$} & $\begin{array}{l}\text { If the hospital has this attribute, how do } \\
\text { you feel? }\end{array}$ & \multicolumn{1}{|l}{$\begin{array}{l}\text { If the hospital does not have this attribute, } \\
\text { how do you feel? }\end{array}$} \\
\cline { 2 - 4 } & I like it & $\sqrt{ }$ & I like it \\
\cline { 2 - 4 } & It must be that way & $\begin{array}{l}\text { I don't mind either way } \\
\text { (I am neutral) }\end{array}$ & $\begin{array}{l}\text { I don't like it, but } \\
\text { I can tolerate it; (live with) }\end{array}$ \\
\cline { 2 - 4 } & $\begin{array}{l}\text { I don't mind either way } \\
\text { I ameutral) }\end{array}$ & $\begin{array}{l}\text { I don't like it and } \\
\text { I cannot tolerate it }\end{array}$ \\
\hline $\begin{array}{l}\text { I don't like it, but } \\
\text { I can tolerate it; (live with) }\end{array}$ & $\begin{array}{l}\text { I don't like it and } \\
\text { I cannot tolerate it }\end{array}$ \\
\hline
\end{tabular}

Tabel 3. Tabel Evaluasi Model Kano (Xu dkk., 2009)

Table 2 Kano evaluation table

\begin{tabular}{lllllll}
\hline & & \multicolumn{5}{c}{ Dysfunctional form of the question } \\
\cline { 3 - 7 } & & Like & Must-be & Neutral & Live with & Dislike \\
\hline Functional from of the question & Like & $\mathrm{Q}$ & $\mathrm{A}$ & $\mathrm{A}$ & $\mathrm{A}$ & $\mathrm{O}$ \\
& Must-be & $\mathrm{R}$ & $\mathrm{I}$ & $\mathrm{I}$ & $\mathrm{I}$ & $\mathrm{M}$ \\
& Neutral & $\mathrm{R}$ & $\mathrm{I}$ & $\mathrm{I}$ & $\mathrm{I}$ & $\mathrm{M}$ \\
& Live with & $\mathrm{R}$ & $\mathrm{I}$ & $\mathrm{I}$ & $\mathrm{I}$ & $\mathrm{M}$ \\
& Dislike & $\mathrm{R}$ & $\mathrm{R}$ & $\mathrm{R}$ & $\mathrm{R}$ & $\mathrm{Q}$ \\
\hline
\end{tabular}

A, Attractive; O, One-dimensional; M, Must-be; I, Indifferent; R, Reverse; Q, Questionable. 


\section{Metode}

Jenis produk yang diamati dalam penelitian ini adalah wastafel. Alasan pertama, produk tersebut memiliki persentasi penjualan produk yang mencapai $70 \%$ dari penjualan produk total (dalam satuan wastafel) pada tahun 2013 dan 56\% dari penjualan produk total pada Januari 2014 sampai dengan Agustus 2014. Alasan kedua, jumlah pesanan wastafel mengalami kenaikan yang cukup signifikan sebesar 25.02\% dari tahun 2011 ke tahun 2012, dan sebesar $31.57 \%$ dari tahun 2012 ke tahun 2013. Alasan ketiga, beberapa contoh (prototype) wastafel yang dihasilkan oleh perusahaan tersebut juga ada yang tidak diterima oleh para (calon) pelanggan.

Tahapan-tahapan yang dilakukan dalam penelitian ini dapat dilihat pada Gambar 3. Atribut kualitas wastafel yang ada pada delapan dimensi kualitas produk (kinerja, estetika, fitur, kesesuaian, kehandalan, durabilitas, kemudahan pelayanan, dan perceived quality) diidentifikasi. Atribut kualitas wastafel yang telah diidentifikasi tersebut disampaikan kepada para responden berkebangsaan Indonesia dan para responden berkebangsaan asing dalam bentuk kuesioner supaya para responden tersebut memberikan penilaian terhadap tingkat penting dari atribut kualitas wastafel.

Populasi responden pada survei tingkat penting tersebut adalah para arsitek, pemborong, produsen wastafel, penjual wastafel, konsumen wastafel, perancang interior ruangan, perancang produk, dan seseorang yang mengerti tentang kualitas wastafel. Akan tetapi, konsumen yang dapat diamati adalah $99 \%$ berkebangsaan Indonesia karena berkenaan dengan kemudahan mencari data. Sampel dari populasi tersebut diambil secara acak.

Atributkualitas wastafel dikelompokkan ke dalam klasifikasi atribut kualitas model Kano untuk kelompok jawaban responden yang berkebangsaan Indonesia. Responden tersebut berprofesi sebagai arsitek, pemborong/pengembang/kontraktor, penjual wastafel, dan masyarakat umum. Sampel dari populasi tersebut diambil secara acak. Sampel tersebut berjumlah 116 responden.

Selain itu, populasi responden pada survei model Kano ini adalah responden yang berkebangsaan asing yang berprofesi sebagai penjual wastafel dan responden yang berkebangsaan asing secara umum. Responden tersebut berjumlah 102 responden dengan komposisi: Eropa (29.41\%), Asia Tenggara (45.1\%), Asia Timur (9.8\%), Asia Selatan (3.92\%), Amerika Utara (3.92\%), Afrika (2.94\%), Amerika Selatan (1.96\%), Australia (0.98\%), Amerika Tengah (0.98\%), dan Asia Barat (0.98\%). Pengambilan sampel dilakukan secara acak. Jumlah sampel dari Eropa lebih kecil dari pada jumlah sampel dari Asia Tenggara karena faktor kemudahan pengumpulan data.

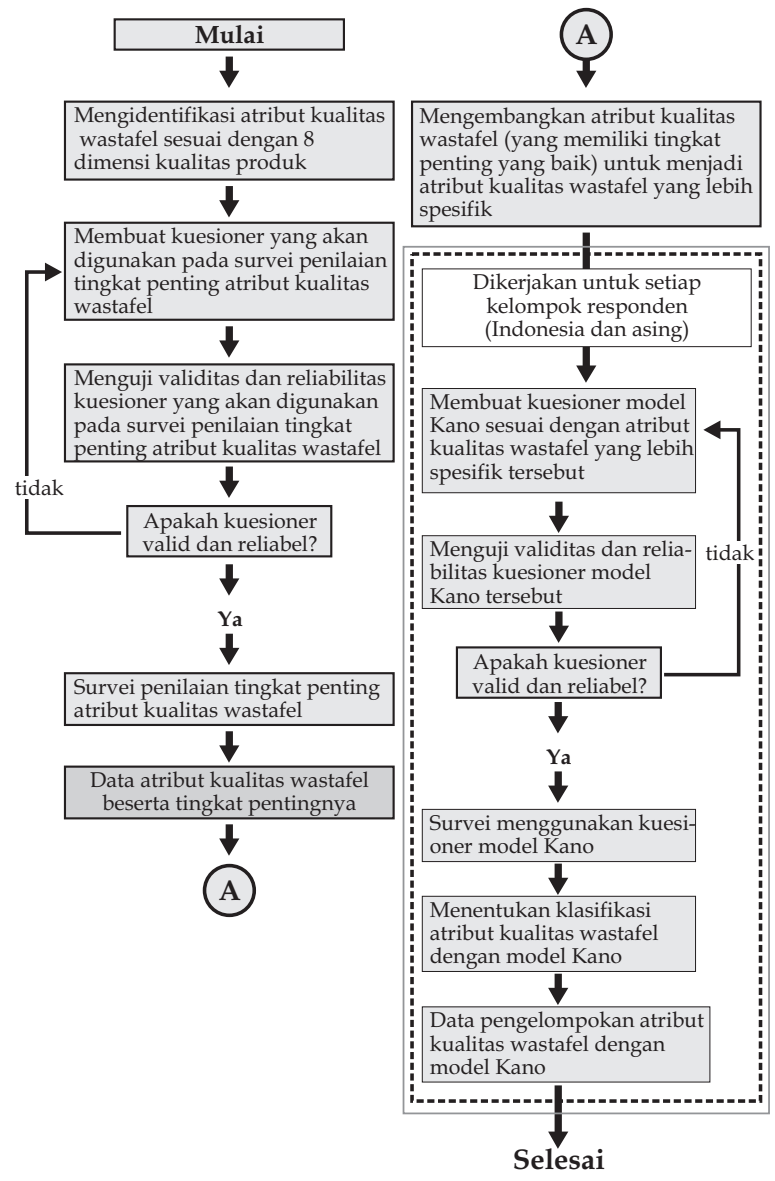

Gambar 3. Tahapan Penelitian 


\section{HASIL DAN PEMBAHASAN Penentuan Atribut Kualitas Wastafel dan Tingkat Pentingnya}

Sembilan puluh sembilan persen responden yang memberikan jawaban pada survei tingkat penting atribut kualitas wastafel berkebangsaan Indonesia, sedangkan res- ponden lain berkebangsaan Belanda dan Prancis. Tujuh puluh satu persen responden tersebut berprofesi sebagai arsitek.

Kuesioner yang dipakai dalam survei tingkat penting atribut kualitas wastafel ini bersifat valid dan reliabel. Hasil uji validitas yang menyatakan bahwa kuesioner tersebut valid dapat dilihat pada Tabel 4-8.

Tabel 4. Hasil Uji Validitas Dimensi Estetika pada Survei Tingkat Penting Atribut Kualitas Wastafel

\begin{tabular}{l|l|l|l|l|l}
\hline Item & $\begin{array}{c}\text { r (korelasi item } \\
\text { terhadap estetika) }\end{array}$ & \multicolumn{1}{|c|}{$\mathbf{t}_{\text {hitung }}$} & \multicolumn{1}{|c|}{$\begin{array}{c}\mathbf{t}_{\text {tabel }}(\mathbf{a}=\mathbf{0 . 0 5} \mathbf{2 2 0 )} \\
\mathbf{v}=20\end{array}$} & Tes Validitas & $\begin{array}{c}\text { Kriteria } \\
\text { Penafsiran }\end{array}$ \\
\hline 2 & 0.6906 & 14.1619 & 1.6450 & valid & tinggi \\
\hline 3 & 0.6658 & 13.2354 & 1.6450 & valid & tinggi \\
\hline 4 & 0.5634 & 10.1142 & 1.6450 & valid & cukup tinggi \\
\hline 5 & 0.4635 & 7.7580 & 1.6450 & valid & cukup tinggi \\
\hline 6 & 0.6886 & 14.0843 & 1.6450 & valid & tinggi \\
\hline 10 & 0.4506 & 7.4861 & 1.6450 & valid & cukup tinggi \\
\hline
\end{tabular}

Tabel 5. Hasil Uji Validitas Dimensi Fitur pada Survei Tingkat Penting Atribut Kualitas Wastafel

\begin{tabular}{|c|c|c|c|c|c|}
\hline Item & $\begin{array}{l}\text { r (korelasi item } \\
\text { terhadap fitur) }\end{array}$ & $\mathbf{t}_{\text {hitung }}$ & $\begin{array}{c}t_{\text {tabel }}(a ́=0.05 ; \\
v=220)\end{array}$ & Tes Validitas & $\begin{array}{c}\text { Kriteria } \\
\text { Penafsiran }\end{array}$ \\
\hline 12 & 0.7352 & 16.0884 & 1.6450 & valid & tinggi \\
\hline 13 & 0.7671 & 17.7349 & 1.6450 & valid & tinggi \\
\hline 14 & 0.6965 & 14.3983 & 1.6450 & valid & tinggi \\
\hline 15 & 0.7548 & 17.0689 & 1.6450 & valid & tinggi \\
\hline
\end{tabular}

Tabel 6. Hasil Uji Validitas Dimensi Kehandalan pada Survei Tingkat Penting Atribut Kualitas Wastafel

\begin{tabular}{l|l|l|l|l|l}
\hline Item & $\begin{array}{c}\text { r (korelasi item } \\
\text { terhadap kehandalan) }\end{array}$ & \multicolumn{1}{|c|}{$\mathbf{t}_{\text {hitung }}$} & \multicolumn{1}{|c|}{$\begin{array}{c}\mathbf{t}_{\text {tabel }}(\mathbf{a}=\mathbf{0 . 0 5} \mathbf{2 2 0 )} \\
\mathbf{v}=20\end{array}$} & Tes Validitas & $\begin{array}{c}\text { Kriteria } \\
\text { Penafsiran }\end{array}$ \\
\hline 16 & 0.8301 & 22.0772 & 1.6450 & valid & sangat tinggi \\
\hline 17 & 0.8476 & 23.6958 & 1.6450 & valid & sangat tinggi \\
\hline 18 & 0.8149 & 20.8546 & 1.6450 & valid & sangat tinggi \\
\hline 19 & 0.7376 & 16.2036 & 1.6450 & valid & tinggi \\
\hline
\end{tabular}

Tabel 7. Hasil Uji Validitas Dimensi Serviceability pada Survei Tingkat Penting Atribut Kualitas Wastafel

\begin{tabular}{|c|c|c|c|c|c|}
\hline Item & $\begin{array}{c}\text { r (korelasi item } \\
\text { terhadap serviceability) }\end{array}$ & $t_{\text {hitung }}$ & $\begin{array}{l}t_{\text {tabel }}(a ́=0.05 ; \\
v=220)\end{array}$ & Tes Validitas & $\begin{array}{c}\text { Kriteria } \\
\text { Penafsiran }\end{array}$ \\
\hline 11 & 0.6659 & 13.2398 & 1.6450 & valid & tinggi \\
\hline 20 & 0.8269 & 21.8113 & 1.6450 & valid & sangat tinggi \\
\hline 21 & 0.8074 & 20.2967 & 1.6450 & valid & sangat tinggi \\
\hline
\end{tabular}

Tabel 8. Hasil Uji Validitas Dimensi Perceived Quality pada Survei Tingkat Penting Atribut Kualitas Wastafel

\begin{tabular}{l|l|l|l|l|l}
\hline Item & \multicolumn{1}{|r|}{$\begin{array}{c}\mathbf{r} \text { (korelasi item terhadap } \\
\text { perceived quality) }\end{array}$} & \multicolumn{1}{|c|}{$\mathbf{t}_{\text {hitung }}$} & $\begin{array}{c}\mathbf{t}_{\text {tabel }}(\mathbf{a}=\mathbf{0 . 0 5} \\
\mathbf{v}=\mathbf{2 2 0})\end{array}$ & Tes Validitas & $\begin{array}{c}\text { Kriteria } \\
\text { Penafsiran }\end{array}$ \\
\hline 22 & 0.9590 & 50.1775 & 1.6450 & valid & sangat tinggi \\
\hline 23 & 0.9532 & 46.7548 & 1.6450 & valid & sangat tinggi \\
\hline
\end{tabular}


Kuesioner yang reliabel ditunjukkan dengan nilai Cronbach's a yang bernilai di atas 0.7 dan dengan beberapa nilai Cronbach's a dimensi kualitas wastafel yang bernilai 0.7 jika dibulatkan ke atas (Tabel 9).
Hasil uji reliabilitas tersebut menunjukkan bahwa masing-masing dimensi kualitas wastafel (kinerja, estetika, fitur, kehandalan, serviceability, dan perceived quality) bersifat satu dimensi.

Tabel 9. Factor Loading pada Survei Tingkat Penting Atribut kualitas Wastafel

\begin{tabular}{|c|c|c|c|c|c|c|}
\hline \multirow[t]{2}{*}{ Item } & \multicolumn{6}{|c|}{ Factor Loading } \\
\hline & Kinerja & Estetika & Fitur & Kehandalan & Serviceability & Perceived Quality \\
\hline 1 & 1.0000 & 0.2598 & 0.2546 & 0.2155 & 0.1543 & 0.0563 \\
\hline 2 & 0.1739 & 0.6906 & 0.1572 & 0.2126 & 0.2262 & 0.1377 \\
\hline 3 & 0.1295 & 0.6658 & 0.1741 & 0.0926 & 0.0315 & 0.0212 \\
\hline 4 & 0.1189 & 0.5634 & 0.3408 & 0.2573 & 0.2017 & 0.2332 \\
\hline 5 & 0.2211 & 0.4635 & 0.1348 & 0.0485 & 0.0926 & 0.0545 \\
\hline 6 & 0.1131 & 0.6886 & 0.3917 & 0.3847 & 0.4025 & 0.3691 \\
\hline 7 & 0.0727 & 0.4506 & 0.1254 & -0.0554 & 0.1533 & 0.1606 \\
\hline 10 & 0.2503 & 0.4619 & 0.4607 & 0.4790 & 0.4654 & 0.2511 \\
\hline 12 & 0.2277 & 0.2323 & 0.7352 & 0.5917 & 0.4608 & 0.2183 \\
\hline 13 & 0.1880 & 0.3387 & 0.7671 & 0.5081 & 0.5092 & 0.3575 \\
\hline 14 & 0.1141 & 0.2853 & 0.6965 & 0.3917 & 0.3692 & 0.3358 \\
\hline 15 & 0.2396 & 0.3870 & 0.7548 & 0.3705 & 0.3423 & 0.2506 \\
\hline 16 & 0.2192 & 0.3096 & 0.5361 & 0.8301 & 0.3881 & 0.3297 \\
\hline 17 & 0.1627 & 0.2587 & 0.4746 & 0.8476 & 0.4437 & 0.3436 \\
\hline 18 & 0.1577 & 0.2585 & 0.4876 & 0.8149 & 0.5313 & 0.2696 \\
\hline 19 & 0.1552 & 0.2310 & 0.4802 & 0.7376 & 0.4867 & 0.3411 \\
\hline 11 & 0.1463 & 0.3796 & 0.4961 & 0.4883 & 0.6659 & 0.2799 \\
\hline 20 & 0.1425 & 0.2963 & 0.3999 & 0.3914 & 0.8269 & 0.3896 \\
\hline 21 & 0.0750 & 0.2163 & 0.4557 & 0.4618 & 0.8074 & 0.4783 \\
\hline 22 & 0.0693 & 0.2832 & 0.3625 & 0.3602 & 0.4716 & 0.9590 \\
\hline 23 & 0.0374 & 0.2821 & 0.3998 & 0.4116 & 0.4884 & 0.9532 \\
\hline Eigenvalue & 0.4072 & 2.0010 & 1.4615 & 1.9817 & 1.2399 & 1.3304 \\
\hline Cronbach's á & & 0.6679 & 0.7197 & 0.8128 & 0.6587 & 0.9051 \\
\hline Varian (\%) & 40.9300 & 4.9966 & 8.2218 & 6.5593 & 14.8776 & 16.5369 \\
\hline Kumulatif (\%) & 40.9300 & 45.9266 & 54.1484 & 60.7077 & 75.5853 & 92.1221 \\
\hline
\end{tabular}

Faktor-faktor apa saja yang menjadi pertimbangan dalam penentuan kualitas wastafel dan tingkat pentingnya dapat dilihat pada Tabel 10 dan 11. Sembilan puluh enam persen atribut kualitas wastafel memiliki tingkat penting rata-rata yang bernilai di antara 'penting' sampai 'luar biasa penting.' 
Tabel 10. Hasil Survei Tingkat Penting Atribut Kualitas Wastafel

\begin{tabular}{|c|c|c|c|c|c|}
\hline \multirow[b]{2}{*}{ Dimensi Kualitas } & \multirow[b]{2}{*}{ Item } & \multicolumn{4}{|c|}{ Tingkat Penting (Skala 1 - 5) } \\
\hline & & $x$ bar & $S$ & $\begin{array}{l}\text { Jumlah data yang dibutuhkan } \\
\qquad(a=0.05 ; \mathrm{e}=0.16)\end{array}$ & n \\
\hline Kinerja & 1 & 4.1276 & 0.6398 & 61.4188 & 196 \\
\hline \multirow{7}{*}{ Estetika } & 2 & 3.0315 & 1.0040 & 151.2707 & 222 \\
\hline & 3 & 3.4054 & 0.9549 & 136.8309 & 222 \\
\hline & 4 & 3.9054 & 0.7874 & 93.0343 & 222 \\
\hline & 5 & 3.8063 & 0.8736 & 114.5304 & 222 \\
\hline & 6 & 3.7523 & 0.9546 & 136.7360 & 222 \\
\hline & 7 & 2.5901 & 0.9362 & 131.5241 & 222 \\
\hline & 10 & 4.5315 & 0.6497 & 63.3381 & 222 \\
\hline \multirow{4}{*}{ Fitur } & 12 & 4.2162 & 0.7599 & 86.6571 & 222 \\
\hline & 13 & 4.2207 & 0.7616 & 87.0394 & 222 \\
\hline & 14 & 3.6847 & 0.9319 & 130.3221 & 222 \\
\hline & 15 & 4.2793 & 0.8035 & 96.8852 & 222 \\
\hline \multirow{4}{*}{ Kehandalan } & 16 & 3.9324 & 0.9223 & 127.6458 & 222 \\
\hline & 17 & 3.8559 & 0.9734 & 142.1774 & 222 \\
\hline & 18 & 4.2072 & 0.7916 & 94.0223 & 222 \\
\hline & 19 & 4.4640 & 0.7283 & 79.5886 & 222 \\
\hline \multirow{3}{*}{ Serviceability } & 11 & 4.5676 & 0.6256 & 58.7257 & 222 \\
\hline & 20 & 3.7523 & 0.9257 & 128.5879 & 222 \\
\hline & 21 & 4.1667 & 0.8531 & 109.2084 & 222 \\
\hline \multirow[b]{2}{*}{ Perceived Quality } & 22 & 3.7973 & 0.8819 & 116.7081 & 222 \\
\hline & 23 & 3.7883 & 0.8267 & 102.5650 & 222 \\
\hline
\end{tabular}

Tabel 11. Tingkat Penting pada Dimensi Kualitas Wastafel

\begin{tabular}{|l|l|l|l|}
\hline $\begin{array}{c}\text { Dimensi } \\
\text { Kualitas }\end{array}$ & $\begin{array}{c}\text { No. } \\
\text { Item }\end{array}$ & \multicolumn{1}{|c|}{ Keterangan Atribut Kualitas } & \multicolumn{1}{|c|}{$\begin{array}{c}\text { Tingkat pen- } \\
\text { ting rata-rata }\end{array}$} \\
\hline Kinerja & 1 & Wastafel dapat digunakan sebagai tempat untuk membersihkan diri & 4.13 \\
\hline Estetika & 2 & Gaya wastafel \{klasik (kuno/antik), modern, atau alami\} & 3.03 \\
\cline { 2 - 5 } & 3 & Bentuk wastafel & 3.41 \\
\cline { 2 - 5 } & 4 & Bahan yang digunakan untuk membuat wastafel & 3.91 \\
\cline { 2 - 5 } & 5 & Cara peletakkan wastafel & 3.81 \\
\cline { 2 - 5 } & 6 & $\begin{array}{l}\text { Hasil akhir permukaan wastafel \{warna, motif, bentuk permukaan } \\
\text { luar (halus/kasar)\} }\end{array}$ & 3.75 \\
\cline { 2 - 5 } & 7 & $\begin{array}{l}\text { Wastafel ditawarkan kepada pelanggan sekaligus dengan } \\
\text { kabinetnya. }\end{array}$ & 2.59 \\
\cline { 2 - 5 } & 10 & $\begin{array}{l}\text { Air dapat keluar melalui lubang pembuangan air dengan cepat dan } \\
\text { sempurna (tidak ada air yang tersisa di dalam wastafel) }\end{array}$ & 4.53 \\
\cline { 2 - 5 } & 12 & $\begin{array}{l}\text { Wastafel dapat dipasang dengan aman dan mudah pada tempat } \\
\text { pemasangannya. }\end{array}$ & 4.22 \\
\cline { 2 - 5 } & 13 & $\begin{array}{l}\text { Kemasan wastafel bersifat bersih, kering, kuat, dan aman dalam } \\
\text { melindungi wastafel. }\end{array}$ & 4.22 \\
\cline { 2 - 5 } & 15 & $\begin{array}{l}\text { Wastafel memiliki harga yang kompetitif di pasar. } \\
\text { Dimensi nyata wastafel sesuai dengan spesifikasinya (panjang, lebar, } \\
\text { tinggi, lubang pemasangan keran air, lubang pembuangan air, semua } \\
\text { sudut bagian dalam bersifat bersih dan sempurna, dll.). }\end{array}$ & 4.28 \\
\hline
\end{tabular}


Tabel 11. Daftar Tingkat Penting pada Dimensi Kualitas Wastafel (lanjutan)

\begin{tabular}{|l|l|l|l|}
\hline $\begin{array}{c}\text { Dimensi } \\
\text { Kualitas }\end{array}$ & $\begin{array}{l}\text { No. } \\
\text { Item }\end{array}$ & \multicolumn{1}{|c|}{ Keterangan Atribut Kualitas } & \multicolumn{1}{|c|}{$\begin{array}{l}\text { Tingkat pen- } \\
\text { ting rata-rata }\end{array}$} \\
\hline Kehandalan & 16 & Warna wastafel bersifat tahan lama (tidak mudah pudar). & 3.93 \\
\cline { 2 - 4 } & 17 & Wastafel bersifat tahan terhadap goresan. & 3.86 \\
\cline { 2 - 4 } & 18 & $\begin{array}{l}\text { Wastafel bersifat tahan terhadap perubahan suhu yang mendadak } \\
\text { (misalnya, terkena air panas). }\end{array}$ & 4.21 \\
\cline { 2 - 4 } & 19 & Wastafel bersifat tidak mudah retak dan patah (tahan benturan). & 4.46 \\
\hline $\begin{array}{l}\text { Service- } \\
\text { ability }\end{array}$ & 11 & $\begin{array}{l}\text { Permukaan wastafel bersifat tahan air (waterproof), sehingga } \\
\text { permukaan tersebut tidak menyerap kotoran, minyak, dan bakteri } \\
\text { (sangat higienis). }\end{array}$ & 4.57 \\
\cline { 2 - 4 } & 20 & $\begin{array}{l}\text { Wastafel dikirim ke pelanggan dengan disertakan bahan yang } \\
\text { digunakan untuk perawatannya, sehingga perawatannya menjadi } \\
\text { mudah. }\end{array}$ & 3.75 \\
\cline { 2 - 4 } & 21 & $\begin{array}{l}\text { Keluhan pelanggan (komunikasi) dapat ditangani dengan baik, } \\
\text { akurat, dan cepat. }\end{array}$ & 4.17 \\
\hline $\begin{array}{l}\text { Perceived } \\
\text { Quality }\end{array}$ & 22 & $\begin{array}{l}\text { Produsen/penjual wastafel memiliki rekam jejak yang baik dalam } \\
\text { bisnis (nama baiknya dalam kualitas produk). }\end{array}$ & 3.80 \\
\cline { 2 - 4 } & 23 & $\begin{array}{l}\text { Produsen/penjual wastafel memiliki rekam jejak yang baik dalam } \\
\text { bisnis (nama baiknya dalam pengiriman produk yang tepat waktu). }\end{array}$ & 3.79 \\
\hline
\end{tabular}

Penentuan Klasifikasi Atribut Kualitas Wastafel dengan Model Kano dan Data Responden Berkebangsaan Indonesia

Seluruh atribut kualitas wastafel yang memiliki tingkat penting yang bagus tersebut dimasukkan ke dalam kuesioner model Kano. Hal tersebut digunakan untuk mengetahui pengaruh dari pemenuhan kualitas terhadap kepuasan (calon) konsumen.

Hasil uji validitas dan reliabilitas kuesioner model Kano dengan data dari responden yang berkebangsaan Indonesia menunjukkan bahwa kuesioner tersebut valid dan reliabel. Hasil uji validitas kuesioner tersebut dapat dilihat pada Tabel 12 dan 13. Pada uji reliabilitas, ada beberapa item yang jika dihilangkan akan meningkatkan reliabilitas kuesioner sebesar 0.0249 (dimensi estetika), 0.0014, 0.0005, 0.0023, 0.0017, $0.0350,0.0042,0.0011$, atau 0.0027, tetapi item tersebut tetap dipakai dalam kuesioner tersebut karena penghapusan item tersebut hanya akan menaikkan reliabilitas kuesioner dalam jumlah yang kecil (Tabel 14).

Tabel 12. Hasil Uji Validitas Kuesioner Model Kano pada Sisi Functional Answer dengan Data dari Responden yang Berkebangsaan Indonesia

\begin{tabular}{|c|c|c|c|c|c|}
\hline \multirow{2}{*}{$\begin{array}{l}\text { Dimensi/ } \\
\text { Item }\end{array}$} & \multicolumn{5}{|c|}{ Functional Answer } \\
\hline & $\begin{array}{c}\mathbf{r} \text { (korelasi } \\
\text { item terhadap } \\
\text { dimensinya) }\end{array}$ & $\mathbf{t}_{\text {hitung }}$ & 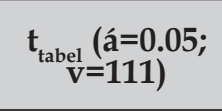 & Tes Validitas & $\begin{array}{c}\text { Kriteria } \\
\text { Penafsiran }\end{array}$ \\
\hline \multicolumn{6}{|l|}{ Kinerja } \\
\hline 1 & 1.0000 & & & valid & sangat tinggi \\
\hline \multicolumn{6}{|l|}{ Estetika } \\
\hline 2 & 0.3995 & 4.591 & 1.660 & valid & rendah \\
\hline 3 & 0.3806 & 4.337 & 1.660 & valid & rendah \\
\hline 4 & 0.4252 & 4.949 & 1.660 & valid & cukup tinggi \\
\hline 5 & 0.5386 & 6.735 & 1.660 & valid & cukup tinggi \\
\hline 6 & 0.3849 & 4.394 & 1.660 & valid & rendah \\
\hline
\end{tabular}




\begin{tabular}{|c|c|c|c|c|c|}
\hline \multirow{2}{*}{$\begin{array}{l}\text { Dimensi/ } \\
\text { Item }\end{array}$} & \multicolumn{5}{|c|}{ Functional Answer } \\
\hline & $\begin{array}{c}\mathbf{r} \text { (korelasi } \\
\text { item terhadap } \\
\text { dimensinya) }\end{array}$ & $\mathbf{t}_{\text {hitung }}$ & $\begin{array}{c}t_{\text {tabel }}\left(\begin{array}{l}(\mathbf{a}=0.05 \\
\mathbf{v}=111)\end{array}\right. \\
\end{array}$ & Tes Validitas & $\begin{array}{c}\text { Kriteria } \\
\text { Penafsiran }\end{array}$ \\
\hline 7 & 0.3652 & 4.133 & 1.660 & valid & rendah \\
\hline 8 & 0.3920 & 4.489 & 1.660 & valid & rendah \\
\hline 9 & 0.2191 & 2.365 & 1.660 & valid & rendah \\
\hline 10 & 0.4835 & 5.819 & 1.660 & valid & cukup tinggi \\
\hline 11 & 0.6513 & 9.043 & 1.660 & valid & tinggi \\
\hline 12 & 0.5050 & 6.164 & 1.660 & valid & cukup tinggi \\
\hline 13 & 0.6756 & 9.656 & 1.660 & valid & tinggi \\
\hline 14 & 0.4420 & 5.191 & 1.660 & valid & cukup tinggi \\
\hline 15 & 0.4136 & 4.787 & 1.660 & valid & cukup tinggi \\
\hline 16 & 0.4689 & 5.594 & 1.660 & valid & cukup tinggi \\
\hline 19 & 0.3350 & 3.746 & 1.660 & valid & rendah \\
\hline \multicolumn{6}{|l|}{ Fitur } \\
\hline 21 & 0.725 & 11.094 & 1.660 & valid & tinggi \\
\hline 22 & 0.802 & 14.129 & 1.660 & valid & \begin{tabular}{|l|} 
sangat tinggi \\
\end{tabular} \\
\hline 23 & 0.713 & 10.715 & 1.660 & valid & tinggi \\
\hline 24 & 0.700 & 10.323 & 1.660 & valid & tinggi \\
\hline \multicolumn{6}{|l|}{ Kehandalan } \\
\hline 25 & 0.649 & 8.983 & 1.660 & valid & tinggi \\
\hline 26 & 0.761 & 12.369 & 1.660 & valid & tinggi \\
\hline 27 & 0.758 & 12.262 & 1.660 & valid & tinggi \\
\hline 28 & 0.556 & 7.043 & 1.660 & valid & cukup tinggi \\
\hline \multicolumn{6}{|l|}{ Serviceability } \\
\hline 20 & 0.692 & 10.110 & 1.660 & valid & tinggi \\
\hline 29 & 0.831 & 15.735 & 1.660 & valid & \begin{tabular}{|l|} 
sangat tinggi \\
\end{tabular} \\
\hline 30 & 0.765 & 12.527 & 1.660 & valid & tinggi \\
\hline \multicolumn{6}{|c|}{ Perceived Quality } \\
\hline 31 & 0.824 & 15.339 & 1.660 & \begin{tabular}{|l|} 
valid \\
\end{tabular} & \begin{tabular}{|l|} 
sangat tinggi \\
\end{tabular} \\
\hline 32 & 0.852 & 17.119 & 1.660 & valid & sangat tinggi \\
\hline
\end{tabular}

Tabel 13. Hasil Uji Validitas Kuesioner Model Kano pada Sisi Dysfunctional Answer dengan Data dari Responden Berkebangsaan Indonesia

\begin{tabular}{|c|c|c|c|c|c|}
\hline \multirow{2}{*}{$\begin{array}{l}\text { Dimensi/ } \\
\text { Item }\end{array}$} & \multicolumn{5}{|c|}{ Dysfunctional Answer } \\
\hline & $\begin{array}{c}\mathrm{r} \text { (korelasi } \\
\text { item terhadap } \\
\text { dimensinya) }\end{array}$ & $\mathbf{t}_{\text {hitung }}$ & $\begin{array}{c}t_{\text {tabel }}(a ́=0.05 ; \\
v=111)\end{array}$ & $\begin{array}{c}\text { Tes } \\
\text { Validitas }\end{array}$ & $\begin{array}{c}\text { Kriteria } \\
\text { Penafsiran }\end{array}$ \\
\hline \multicolumn{6}{|l|}{ Kinerja } \\
\hline 1 & 1 & & & valid & sangat tinggi \\
\hline \multicolumn{6}{|l|}{ Estetika } \\
\hline 2 & 0.4414 & 5.182851 & 1.65995 & valid & cukup tinggi \\
\hline 3 & 0.4567 & 5.408191 & 1.65995 & valid & cukup tinggi \\
\hline 4 & 0.2900 & 3.193125 & 1.65995 & valid & rendah \\
\hline 5 & 0.4261 & 4.961789 & 1.65995 & valid & cukup tinggi \\
\hline
\end{tabular}




\begin{tabular}{|c|c|c|c|c|c|}
\hline \multirow{2}{*}{$\begin{array}{l}\text { Dimensi/ } \\
\text { Item }\end{array}$} & \multicolumn{5}{|c|}{ Dysfunctional Answer } \\
\hline & $\begin{array}{c}\mathbf{r} \text { (korelasi } \\
\text { item terhadap } \\
\text { dimensinya) }\end{array}$ & $\mathbf{t}_{\text {hitung }}$ & $\begin{array}{c}\mathbf{t}_{\text {tabel }}(\mathbf{a}=0.05 ; \\
\mathbf{v}=111)\end{array}$ & $\begin{array}{c}\text { Tes } \\
\text { Validitas }\end{array}$ & $\begin{array}{l}\text { Kriteria } \\
\text { Penafsiran }\end{array}$ \\
\hline 6 & 0.4393 & 5.151548 & 1.65995 & valid & cukup tinggi \\
\hline 7 & 0.5012 & 6.103013 & 1.65995 & valid & cukup tinggi \\
\hline 8 & 0.4544 & 5.374635 & 1.65995 & valid & cukup tinggi \\
\hline 9 & 0.3480 & 3.911189 & 1.65995 & valid & rendah \\
\hline 10 & 0.5288 & 6.563370 & 1.65995 & valid & cukup tinggi \\
\hline 11 & 0.5771 & 7.445695 & 1.65995 & valid & cukup tinggi \\
\hline 12 & 0.4554 & 5.389148 & 1.65995 & valid & cukup tinggi \\
\hline 13 & 0.5458 & 6.863290 & 1.65995 & valid & cukup tinggi \\
\hline 14 & 0.5843 & 7.585973 & 1.65995 & valid & cukup tinggi \\
\hline 15 & 0.5022 & 6.118501 & 1.65995 & valid & cukup tinggi \\
\hline 16 & 0.3817 & 4.351101 & 1.65995 & valid & rendah \\
\hline 19 & 0.2781 & 3.050823 & 1.65995 & valid & rendah \\
\hline \multicolumn{6}{|l|}{ Fitur } \\
\hline 21 & 0.755 & 12.12903 & 1.65995 & valid & tinggi \\
\hline 22 & 0.746 & 11.79916 & 1.65995 & valid & tinggi \\
\hline 23 & 0.676 & 9.670238 & 1.65995 & valid & tinggi \\
\hline 24 & 0.680 & 9.780161 & 1.65995 & valid & tinggi \\
\hline \multicolumn{6}{|l|}{ Kehandalan } \\
\hline 25 & 0.725 & 11.10094 & 1.65995 & valid & tinggi \\
\hline 26 & 0.843 & 16.49719 & 1.65995 & valid & sangat tinggi \\
\hline 27 & 0.768 & 12.64426 & 1.65995 & valid & tinggi \\
\hline 28 & 0.664 & 9.361579 & 1.65995 & valid & tinggi \\
\hline \multicolumn{6}{|l|}{ Serviceability } \\
\hline 20 & 0.614 & 8.198525 & 1.65995 & valid & tinggi \\
\hline 29 & 0.776 & 12.94956 & 1.65995 & valid & tinggi \\
\hline 30 & 0.802 & 14.14919 & 1.65995 & valid & sangat tinggi \\
\hline \multicolumn{6}{|c|}{ Perceived Quality } \\
\hline 31 & 0.835 & 16.0159 & 1.65995 & valid & sangat tinggi \\
\hline 32 & 0.836 & 16.0588 & 1.65995 & valid & sangat tinggi \\
\hline
\end{tabular}

Tabel 14. Hasil Uji Reliabilitas Kuesioner Model Kano dengan Data dari Responden Berkebangsaan Indonesia

\begin{tabular}{|c|c|c|c|c|}
\hline \multirow{3}{*}{$\begin{array}{l}\text { Dimensi/Item } \\
\text { (i) }\end{array}$} & \multicolumn{4}{|c|}{ Cronbach's alpha jika item dihapus $\left(a_{i}\right)$} \\
\hline & \multicolumn{2}{|c|}{ Functional Answer $_{(1)}$} & \multicolumn{2}{|c|}{\begin{tabular}{|l} 
Dysfunctional Answer \\
${ }_{(2)}$
\end{tabular}} \\
\hline & $\dot{a}_{\mathrm{i} 1}$ & $\dot{a}_{\mathrm{i1}}-\dot{a}_{\text {total1 }}$ & $a_{i_{2}}$ & $\hat{a}_{\mathrm{i} 2}-\hat{a}_{\text {total2 }}$ \\
\hline Kinerja & 0.7747 & -0.0046 & 0.7876 & -0.0090 \\
\hline 1 & 0.7747 & -0.0046 & 0.7876 & -0.0090 \\
\hline Estetika & 0.8042 & 0.0249 & 0.8316 & 0.0350 \\
\hline 2 & 0.7807 & 0.0014 & 0.7948 & -0.0017 \\
\hline 3 & 0.7798 & 0.0005 & 0.7916 & -0.0050 \\
\hline 4 & 0.7764 & -0.0029 & 0.8008 & 0.0042 \\
\hline 5 & 0.7687 & -0.0106 & 0.7904 & -0.0062 \\
\hline
\end{tabular}




\begin{tabular}{|c|c|c|c|c|}
\hline \multirow{3}{*}{$\begin{array}{l}\text { Dimensi/Item } \\
\text { (i) }\end{array}$} & \multicolumn{4}{|c|}{ Cronbach's alpha jika item dihapus $\left(a_{i}\right)$} \\
\hline & \multicolumn{2}{|c|}{ Functional Answer } & \multicolumn{2}{|c|}{ Dysfunctional Answer ${ }_{(2)}$} \\
\hline & $\dot{a}_{i 1}$ & $\dot{a}_{i 1}-\hat{a}_{\text {total1 }}$ & $a_{\mathrm{i} 2}$ & $\hat{a}_{\mathrm{i2} 2}-\hat{a}_{\text {total2 }}$ \\
\hline 6 & 0.7775 & -0.0018 & 0.7950 & -0.0016 \\
\hline 7 & 0.7749 & -0.0044 & 0.7886 & -0.0080 \\
\hline 8 & 0.7723 & -0.0070 & 0.7977 & 0.0011 \\
\hline 9 & 0.7816 & 0.0023 & 0.7992 & 0.0027 \\
\hline 10 & 0.7739 & -0.0054 & 0.7893 & -0.0072 \\
\hline 11 & 0.7610 & -0.0183 & 0.7907 & -0.0059 \\
\hline 12 & 0.7652 & -0.0141 & 0.7940 & -0.0026 \\
\hline 13 & 0.7577 & -0.0216 & 0.7946 & -0.0020 \\
\hline 14 & 0.7729 & -0.0064 & 0.7923 & -0.0043 \\
\hline 15 & 0.7774 & -0.0019 & 0.7964 & -0.0002 \\
\hline 16 & 0.7693 & -0.0100 & 0.7902 & -0.0064 \\
\hline 19 & 0.7726 & -0.0067 & 0.7883 & -0.0083 \\
\hline Fitur & 0.7524 & -0.0268 & 0.7631 & -0.0335 \\
\hline 21 & 0.7714 & -0.0078 & 0.7842 & -0.0123 \\
\hline 22 & 0.7688 & -0.0105 & 0.7860 & -0.0106 \\
\hline 23 & 0.7766 & -0.0027 & 0.7904 & -0.0062 \\
\hline 24 & 0.7729 & -0.0064 & 0.7907 & -0.0059 \\
\hline Kehandalan & 0.7656 & -0.0137 & 0.7698 & -0.0268 \\
\hline 25 & 0.7729 & -0.0064 & 0.7856 & -0.0110 \\
\hline 26 & 0.7755 & -0.0038 & 0.7918 & -0.0048 \\
\hline 27 & 0.7715 & -0.0078 & 0.7843 & -0.0123 \\
\hline 28 & 0.7810 & 0.0017 & 0.7926 & -0.0040 \\
\hline Serviceability & 0.7608 & -0.0184 & 0.7755 & -0.0211 \\
\hline 20 & 0.7745 & -0.0048 & 0.7826 & -0.0140 \\
\hline 29 & 0.7689 & -0.0104 & 0.7936 & -0.0030 \\
\hline 30 & 0.7752 & -0.0041 & 0.7918 & -0.0048 \\
\hline Perceived Quality & 0.7737 & -0.0056 & 0.7768 & -0.0197 \\
\hline 31 & 0.7773 & -0.0020 & 0.7884 & -0.0082 \\
\hline 32 & 0.7750 & -0.0042 & 0.7850 & -0.0115 \\
\hline Total & 0.7793 & 0.0000 & 0.7966 & 0.0000 \\
\hline
\end{tabular}

Hasil klasifikasi atribut kualitas wastafel dengan model Kano dijelaskan dalam beberapa poin pada (calon) pelanggan yang berkebangsaan Indonesia. Pertama, fungsi dasar wastafel sebagai tempat untuk membersihkan

diri merupakan hal yang sangat utama atau dasar (Tabel 15). Ketidakterpenuhinya kebutuhan pada dimensi kualitas kinerja ini akan menimbulkan ketidakpuasan konsumen yang sangat tinggi.

Tabel 15. Klasifikasi Atribut Kualitas dari Dimensi Kinerja dengan Data dari Responden Berkebangsaan Indonesia dan Asing

\begin{tabular}{l|l|c|c}
\hline \multirow{2}{*}{ No. } & \multicolumn{1}{c}{ Deskripsi Atribut } & \multicolumn{2}{c}{ Klasifikasi } \\
\cline { 3 - 4 } & \multicolumn{1}{|c|}{$\begin{array}{l}\text { Indo-nesia } \\
\text { menstafel dapat digunakan sebagai tempat untuk membersihkan diri, seperti }\end{array}$} & $\mathrm{M}$ & $\mathrm{M}$ \\
\hline 1 & muka, mencuci tangan, menggosok gigi, dan/atau bercukur. & & \\
\hline
\end{tabular}

A: attractive quality attributes; O: one-dimensional quality attributes; M: must-be quality attributes; I: indifferent quality attributes 
Kedua, 50 \% atribut kualitas dimensi estetika masuk ke dalam kategori attractive quality attributes (Tabel 16). Akan tetapi, kehalusan dan kemiringan permukaan bagian dalam wastafel yang mendukung kelancaran air ke luar wastafel merupakan must-be quality attributes, jika atribut kualitas ini tidak dipenuhi maka konsumen akan merasa sangat kecewa karena sisi keindahan wastafel menjadi rendah. Atribut kualitas yang dapat menjadi pilihan untuk dikembangkan agar kepuasan konsumen dapat naik dengan sangat cepat adalah (1) wastafel bergaya modern, (2) wastafel bergaya alami yang berbahan utama terazo,
(3) wastafel dirancang untuk bergaya sedikit muncul di atas permukaan meja, (4) wastafel dirancang untuk dipasang di bawah meja, (5) wastafel ditawarkan kepada konsumen sekaligus dengan almarinya dengan rak-rak almari yang juga dapat dibuat dari terazo, (6) lubang pembuangan air dibuat berbeda dari biasanya, (7) wastafel dirancang untuk bersayap lebar, dan (8) hasil akhir permukaan luar wastafel (warna, motif) dibuat indah. Atribut kualitas wastafel yang termasuk indifferent quality attributes tidak perlu dikembangkan karena tidak menimbulkan kepuasan konsumen dan tidak menimbulkan ketidakpuasan konsumen.

Tabel 16. Klasifikasi Atribut Kualitas dari Dimensi Estetika dengan Data dari Responden Berkebangsaan Indonesia dan Asing

\begin{tabular}{l|l|l|l}
\hline \multirow{2}{*}{ No. } & \multicolumn{1}{|c|}{ Deskripsi Atribut } & \multicolumn{2}{c}{ Klasifikasi } \\
\hline 2 & Wastafel bergaya klasik (kuno). & Indonesia & \multicolumn{1}{|c}{ Asing } \\
\hline 3 & Wastafel bergaya modern. & A & A \\
\hline 4 & $\begin{array}{l}\text { Wastafel bergaya alami (wastafel terbuat dari } \\
\text { semen). }\end{array}$ & I & A \\
\hline 5 & $\begin{array}{l}\text { Wastafel bergaya alami (wastafel terbuat dari } \\
\text { terazo). }\end{array}$ & A & \\
\hline 6 & $\begin{array}{l}\text { Wastafel berkaki. Kaki wastafel menopang beban } \\
\text { dari wastafel dan menutupi perpipaan. }\end{array}$ & I & I \\
\hline 7 & Wastafel diletakkan di atas meja. & A & A \\
\hline 9 & Wastafel diletakkan di bawah meja. & & \\
\hline
\end{tabular}




\begin{tabular}{l|l|l|l|l}
\hline \multirow{2}{*}{ No. } & \multicolumn{1}{|c|}{ Deskripsi Atribut } & \multicolumn{2}{c}{ Klasifikasi } \\
\cline { 3 - 5 } & $\begin{array}{l}\text { Wastafel ditawarkan kepada pelanggan dengan } \\
\text { kabinetnya. (Raknya dapat dibuat dari terazo) }\end{array}$ & Indonesia & \multicolumn{1}{c}{ Asing } \\
\hline 11 & $\begin{array}{l}\text { Beberapa permukaan wastafel berpola garis- } \\
\text { garis. }\end{array}$ & $\mathrm{I}$ & $\mathrm{A}$ \\
\hline 12 & $\begin{array}{l}\text { Permukaan luar wastafel bersifat kasar secara } \\
\text { teratur. }\end{array}$ & $\mathrm{I}$ & $\mathrm{I}$ \\
\hline
\end{tabular}

A: attractive quality attributes; O: one-dimensional quality attributes; M: must-be quality attributes; I: indifferent quality attributes

Tabel 16. Klasifikasi Atribut Kualitas dari Dimensi Estetika dengan Data dari Responden Berkebangsaan Indonesia dan Asing (lanjutan)

\begin{tabular}{|c|c|c|c|}
\hline \multirow{2}{*}{ No. } & \multirow{2}{*}{ Deskripsi Atribut } & \multicolumn{2}{|c|}{ Klasifikasi } \\
\hline & & Indonesia & Asing \\
\hline 13 & $\begin{array}{l}\text { Beberapa permukaan wastafel bersifat kasar } \\
\text { secara tidak teratur. }\end{array}$ & I & $\mathrm{I}$ \\
\hline 14 & $\begin{array}{l}\text { Lubang pembuangan air wastafel bersifat unik } \\
\text { (berbeda dari wastafel lain). }\end{array}$ & A & A \\
\hline 15 & Permukaan wastafel juga berfungsi sebagai meja. & A & A \\
\hline 16 & Hasil akhir (warna, sebaran butiran terazo) bersifat elegan (indah). & A & A \\
\hline 19 & $\begin{array}{l}\text { Air dapat keluar melalui lubang pembuangan air dengan cepat dan } \\
\text { sempurna, karena permukaan wastafel yang halus dan miring. }\end{array}$ & $\mathrm{M}$ & M \\
\hline
\end{tabular}

Ketiga, $50 \%$ atribut kualitas dari dimensi fitur berada pada klasifikasi one-dimensional quality attributes (Tabel 17). Wastafel sebaiknya dirancang sedemikian rupa sehingga dapat dipasang dengan mudah oleh pengguna, semakin mudah dipasang, maka konsumen akan semakin puas, dan sebaliknya. Dimensi nyata dari wastafel juga harus sesuai dengan spesifikasi produk yang sudah ditentukan pada saat perancangan, agar kepuasan konsumen semakin naik, jika tidak demikian kepuasan konsumen akan turun secara linear.

Tabel 17. Klasifikasi Atribut Kualitas dari Dimensi Fitur dengan Data dari Responden Berkebangsaan Indonesia dan Asing

\begin{tabular}{l|l|l|l}
\hline \multirow{2}{*}{ No. } & \multicolumn{1}{c|}{ Deskripsi Atribut } & \multicolumn{1}{c}{ Klasifikasi } \\
\cline { 3 - 4 } & \multicolumn{1}{|c}{ Indonesia } & \multicolumn{1}{c}{ Asing } \\
\hline 21 & $\begin{array}{l}\text { Wastafel dapat dipasang dengan aman dan mudah pada tempat } \\
\text { pemasangannya. }\end{array}$ & $\mathrm{O}$ & $\mathrm{O}$ \\
\hline 22 & $\begin{array}{l}\text { Kemasan wastafel bersifat bersih, kering, kuat, dan aman dalam } \\
\text { melindungi wastafel. }\end{array}$ & $\mathrm{M}$ & $\mathrm{M}$ \\
\hline
\end{tabular}




\begin{tabular}{l|l|l|l}
\hline \multirow{2}{*}{ No. } & \multicolumn{1}{|c|}{ Deskripsi Atribut } & \multicolumn{2}{c}{ Klasifikasi } \\
\cline { 3 - 4 } & \multicolumn{1}{|c}{ Indonesia } & Asing \\
\hline 23 & Wastafel memiliki harga yang kompetitif di pasar. & A & A \\
\hline 24 & $\begin{array}{l}\text { Dimensi nyata wastafel sesuai dengan spesifikasinya (panjang, lebar, } \\
\text { tinggi, kedalaman, lubang pemasangan keran air, lubang pembuangan } \\
\text { air, lubang sumbat pada pembuangan air, semua sudut bagian dalam } \\
\text { bersifat bersih dan sempurna, dll.). }\end{array}$ & O & O \\
\hline
\end{tabular}

A: attractive quality attributes; O: one-dimensional quality attributes; M: must-be quality attributes; I: indifferent quality attributes

Keempat, $75 \%$ atribut kualitas dimensi kehandalan berbanding lurus dengan kepuasan konsumen, semakin wastafel handal, maka konsumen akan semakin puas dan sebaliknya (Tabel 18). Atribut kualitas kehandalan yang pemenuhan kebutuhannya berbanding lurus dengan kepuasan konsu- men adalah warna wastafel yang tahan lama, wastafel yang tahan gores, dan wastafel yang tahan terhadap perubahan suhu yang mendadak. Akan tetapi, ada suatu atribut kualitas yang bersifat harus ada atau dasar, yaitu wastafel harus tidak mudah retak dan pecah.

Tabel 18. Klasifikasi Atribut Kualitas dari Dimensi Kehandalan dengan Data dari Responden Berkebangsaan Indonesia dan Asing

\begin{tabular}{l|l|l|l}
\hline \multirow{2}{*}{ No. } & \multicolumn{1}{|c|}{ Deskripsi Atribut } & \multicolumn{2}{c}{ Klasifikasi } \\
\cline { 3 - 4 } & \multicolumn{1}{|c}{ Indonesia } & \multicolumn{1}{c}{ Asing } \\
\hline 25 & Warna wastafel bersifat tahan lama. & $\mathrm{O}$ & $\mathrm{O}$ \\
\hline 26 & Wastafel bersifat tahan terhadap goresan. & $\mathrm{O}$ & $\mathrm{O}$ \\
\hline 27 & $\begin{array}{l}\text { Wastafel bersifat tahan terhadap perubahan suhu yang mendadak } \\
\text { (misalnya terkena air panas). }\end{array}$ & $\mathrm{O}$ & $\mathrm{A}$ \\
\hline 28 & Wastafel bersifat tidak mudah retak dan patah (tahan benturan). & $\mathrm{M}$ & $\mathrm{M}$ \\
\hline
\end{tabular}

A: attractive quality attributes; O: one-dimensional quality attributes; M: must-be quality attributes; I: indifferent quality attributes

Kelima, atribut kualitas dimensi biasa-biasa saja. Wastafel yang tidak anti serviceability terbagi ke dalam tiga air akan menimbulkan ketidakpuasan klasifikasi atribut kualitas yang berbeda yang tinggi bagi konsumen, sedangkan (Tabel 19). Keluhan pelanggan yang tidak pemenuhan kebutuhan ini meningkatkan dikelola dengan baik akan menimbulkan kepuasan (calon) konsumen. Penyertaan ketidakpuasan yang sangat tinggi bagi bahan perawatan wastafel saat pembelian konsumen, sedangkan jika kebutuhan ini wastafel dapat meningkatkan kepuasan dipenuhi, maka konsumen akan merasa pelanggan dengan sangat cepat.

Tabel 19. Klasifikasi Atribut Kualitas dari Dimensi Serviceability dengan Data dari Responden Berkebangsaan Indonesia dan Asing

\begin{tabular}{l|l|l|l}
\hline \multirow{2}{*}{ No. } & \multicolumn{1}{|c|}{ Deskripsi Atribut } & \multicolumn{2}{c}{ Klasifikasi } \\
\cline { 3 - 4 } & \multicolumn{1}{|c}{ Indonesia } & \multicolumn{1}{c}{ Asing } \\
\hline 20 & $\begin{array}{l}\text { Permukaan wastafel bersifat tahan air, sehingga permukaan tersebut } \\
\text { tidak akan menyerap kotoran, minyak, dan bakteri (sangat higienis). }\end{array}$ & $\mathrm{O}$ & $\mathrm{M}$ \\
\hline 29 & $\begin{array}{l}\text { Wastafel dikirim ke pelanggan dengan disertakan bahan yang digunakan } \\
\text { untuk perawatannya, sehingga perawatannya menjadi mudah. }\end{array}$ & $\mathrm{A}$ & $\mathrm{A}$ \\
\hline 30 & $\begin{array}{l}\text { Keluhan pelanggan (komunikasi) dapat ditangani dengan baik, akurat, } \\
\text { dan cepat. }\end{array}$ & $\mathrm{M}$ & $\mathrm{M}$ \\
\hline
\end{tabular}

A: attractive quality attributes; O: one-dimensional quality attributes; M: must-be quality attributes; I: indifferent quality attributes 
Keenam, atribut kualitas pada dimensi perceived quality yang meliputi nama baik perusahaan pada kualitas produk dan ketepatan waktu pengiriman barang masuk ke dalam klasifikasi attractive quality attributes (Tabel 20). Semakin tinggi nama baik perusahaan maka kepuasan konsumen juga akan semakin naik dengan cepat, dan sebaliknya, jika pemenuhan kebutuhan dimensi ini semakin menurun maka konsumen akan bersikap netral atau biasabiasa saja.

Tabel 20. Klasifikasi Atribut Kualitas dari Dimensi Perceived Quality dengan Data dari Responden Berkebangsaan Indonesia dan Asing

\begin{tabular}{l|l|l|l}
\hline \multirow{2}{*}{ No. } & \multicolumn{1}{|c|}{ Deskripsi Atribut } & \multicolumn{2}{c}{ Klasifikasi } \\
\cline { 3 - 4 } & \multicolumn{1}{|c}{$\begin{array}{l}\text { Indonesia } \\
\text { (nama baiknya dalam kualitas produk). }\end{array}$} & Asing \\
\hline 31 & $\begin{array}{l}\text { Produsen/penjual wastafel memiliki rekam jejak yang baik dalam bisnis } \\
\text { (nama baiknya dalam pengiriman produk yang tepat waktu). }\end{array}$ & A & O \\
\hline
\end{tabular}

A: attractive quality attributes; O: one-dimensional quality attributes; M: must-be quality attributes; I: indifferent quality attributes

Penentuan Klasifikasi Atribut Kualitas Wastafel dengan Model Kano dan dengan Data dari Responden Berkebangsaan Asing

Responden yang berkebangsaan asing yang memberikan respons pada survei model Kano ini berasal dari beberapa kawasan (Tabel 21). Empat puluh lima persen responden berasal dari Asia Tenggara, sedangkan $29 \%$ responden berasal dari Eropa.

Tabel 21. Informasi Responden yang Berkebangsaan Asing pada Survei Model Kano

\begin{tabular}{|c|c|c|c|}
\hline Kawasan & $\begin{array}{c}\text { Jumlah } \\
\text { Responden } \\
\text { (orang) }\end{array}$ & \multicolumn{2}{|c|}{$\begin{array}{c}\text { Jumlah } \\
\text { Responden (\%) }\end{array}$} \\
\hline \multicolumn{4}{|c|}{ Asia Tenggara } \\
\hline Filipina & 4 & 3.9216 & \multirow[t]{4}{*}{45.0980} \\
\hline Singapura & 2 & 1.9608 & \\
\hline Vietnam & 29 & 28.4314 & \\
\hline Malaysia & 11 & 10.7843 & \\
\hline \multicolumn{4}{|l|}{ Eropa } \\
\hline Belanda & 15 & 14.7059 & \multirow[t]{8}{*}{29.4118} \\
\hline Spanyol & 1 & 0.9804 & \\
\hline Roma & 2 & 1.9608 & \\
\hline Prancis & 3 & 2.9412 & \\
\hline Belgia & 6 & 5.8824 & \\
\hline Inggris & 1 & 0.9804 & \\
\hline $\begin{array}{l}\text { Bosnia \& } \\
\text { Herzegovina }\end{array}$ & 1 & 0.9804 & \\
\hline Welsh & 1 & 0.9804 & \\
\hline \multicolumn{4}{|l|}{ Asia Timur } \\
\hline Cina & 1 & 0.9804 & \multirow[t]{3}{*}{9.8039} \\
\hline Jepang & 1 & 0.9804 & \\
\hline Korea & 8 & 7.8431 & \\
\hline
\end{tabular}

\begin{tabular}{|c|c|c|c|}
\hline Kawasan & $\begin{array}{c}\text { Jumlah } \\
\text { Responden } \\
\text { (orang) }\end{array}$ & \multicolumn{2}{|c|}{$\begin{array}{c}\text { Jumlah } \\
\text { Responden (\%) }\end{array}$} \\
\hline \multicolumn{4}{|l|}{ Asia Selatan } \\
\hline India & 1 & 0.9804 & \multirow[t]{3}{*}{3.9216} \\
\hline Nepal & 2 & 1.9608 & \\
\hline Pakistan & 1 & 0.9804 & \\
\hline \multicolumn{4}{|c|}{ Amerika Utara } \\
\hline America & 3 & 2.9412 & \multirow[b]{2}{*}{3.9216} \\
\hline Canada & 1 & 0.9804 & \\
\hline \multicolumn{4}{|l|}{ Afrika } \\
\hline Rwanda & 1 & 0.9804 & \multirow[t]{3}{*}{2.9412} \\
\hline Ghana & 1 & 0.9804 & \\
\hline Nigeria & 1 & 0.9804 & \\
\hline \multicolumn{4}{|c|}{ Amerika Selatan } \\
\hline Brazil & 1 & 0.9804 & \multirow[t]{2}{*}{1.9608} \\
\hline Colombia & 1 & 0.9804 & \\
\hline Australia & 1 & 0.9804 & 0.9804 \\
\hline \multicolumn{4}{|c|}{ Amerika Tengah } \\
\hline Mexiko & 1 & 0.9804 & 0.9804 \\
\hline \multicolumn{4}{|l|}{ Asia Barat } \\
\hline Turki & 1 & 0.9804 & 0.9804 \\
\hline
\end{tabular}


Hasil klasifikasi atribut kualitas wastafel dijelaskan dalam beberapa poin dengan data dari responden yang berkebangsaan asing. Pertama, fungsi dasar wastafel sebagai tempat untuk membersihkan diri merupakan hal yang sangat utama atau dasar (Tabel 15). Kedua, $56 \%$ atribut kualitas dimensi estetika wastafel masuk ke dalam kategori attractive quality attributes (Tabel 16). Ketiga, 50 \% item dari dimensi fitur wastafel berada pada one-dimensional quality attributes (Tabel 17). Keempat, 50 \% item yang ada pada dimensi kehandalan wastafel juga berada pada onedimensional quality attributes (Tabel 18). Kelima, $1 / 3$ atribut kualitas dimensi serviceability masuk ke dalam klasifikasi attractive quality attributes (Tabel 19). Keenam, seluruh atribut kualitas dimensi perceived quality masuk ke dalam klasifikasi one-dimensional quality attributes (Tabel 20).

Atribut kualitas wastafel yang berada pada attractive quality attributes harus segera diluncurkan oleh perusahaan tersebut sebelum klasifikasi atribut tersebut turun menjadi one-dimensional quality attributes, atau bahkan turun ke dalam must-be quality attributes. Jika klasifikasi atribut kualitas tersebut turun, maka kepuasan konsumennya juga akan turun dengan pemenuhan kebutuhan yang sama.

Kualitas wastafel dan kepuasan konsumen dipakai menjadi ukuran produk sukses pada penelitian ini. Hal tersebut dikarenakan kedua ukuran sukses tersebut menjadi pintu masuk bagi kesuksesan produk jangka pendek (diluncurkan tepat waktu) dan jangka panjang (mencapai tujuan-tujuan pendapatan, mencapai tujuantujuan penjualan unit, mencapai tujuantujuan keuntungan, IRR/ROI) (Hultink dan Robben, 1995).

\section{SIMPULAN}

Penelitian ini memberikan tiga kesimpulan, yaitu pertama, Atribut kualitas wastafel tersebar ke dalam 6 dimensi kualitas wastafel dan atribut kualitas tersebut memiliki tingkat penting rata-rata di antara 'penting' dan 'luar biasa penting,' kecuali 'wastafel ditawarkan kepada pelanggan sekaligus dengan kabinetnya' yang memiliki tingkat penting rata-rata di antara nilai 'cukup penting' dan 'penting.'

Kedua, Kebutuhan (calon) pelanggan Indonesia beserta tingkat puas pemenuhan kebutuhan tersebut sebagai berikut: (1) kinerja wastafel sebagi tempat untuk membersihkan diri merupakan fungsi dasar, (2) $89 \%$ atribut kualitas dari dimensi estetika yang bukan indifferent quality attributes masuk ke dalam klasifikasi attractive quality attributes, (3) 'harga wastafel yang kompetitif' dapat meningkatkan kepuasan (calon) pelanggan dengan cepat, (4) $75 \%$ atribut kualitas kehandalan menaikkan kepuasan pelanggan secara linear terhadap pemenuhan kebutuhan, (5) 'penyertaan bahan perawatan saat pembelian' dapat meningkatkan kepuasan konsumen dengan cepat, dan (6) semakin baik reputasi perusahaan maka kepuasan konsumen juga akan semakin naik dengan cepat.

Ketiga, Kebutuhan (calon) pelanggan yang berkebangsaan asing beserta kepuasan pemenuhan kebutuhan tersebut: (1) fungsi wastafel sebagai tempat untuk membersihkan diri tergolong must-be quality attributes, (2) $90 \%$ atribut kualitas dari dimensi estetika yang bukan indifferent quality attributes masuk ke dalam klasifikasi attractive quality attributes, (3) fitur dapat meningkatkan kepuasan konsumen dengan cepat melalui 'harga wastafel yang kompetitif,' (4) 'tahan terhadap perubahan suhu yang mendadak' dapat menaikkan kepuasan (calon) pelanggan dengan cepat, (5) 'penyertaan bahan perawatan saat pembelian' dapat meningkatkan kepuasan (calon) konsumen dengan cepat, dan (6) semakin baik reputasi perusahaan maka kepuasan konsumen juga akan semakin naik secara linear. 


\section{DAFTAR PUSTAKA}

Bennur S and Jin B (2013) Cross-Cultural Investigation of US and Indian Consumer's Apparel Attribute Choices Applying Kano's Theory. Journal of Fashion Marketing and Management 17(3): 306-321.

Chang KC and Chen MC (2011) Applying the Kano Model and QFD to Explore Customers' Brand Contacts in the Hotel Business: A Study of a Hot Spring Hotel. Total Quality Management 22(1): 1-27.

Chang KC, Chen MC and Hsu CL (2012) Identifying Critical Brand Contact Elements of a Tourist Destination: Applications of Kano's Model and the Importance-Satisfaction Model. International Journal of Tourism Research 14: 205-221.

Chang KC and Chen MC (2014) Prioritizing $5 S$ Activities by Kano Model with Modified CS Coefficient for a Semiconductor Wafer Fabrication During Ramp-Up Stage. The TQM Journal 26(2): 109-124.

Chaudha A, Jain R, Singh AR and Mishra PK (2011) Integration of Kano's Model into Quality Function Deployment (QFD). Int J Adv Manuf Technol 53:689-698.

Chen LF (2012) A Novel Approach to Regression Analysis for The Classification of Atribut kualitas in the Kano Model: An Empirical Test in The Food and Beverage Industry. Omega 40: 651-659.

Chen LH and Kuo YF (2011) Understanding E-Learning Service Quality of a Commercial Bank by Using Kano's Model. Total Quality Management, 22(1): 99-116.

Cheng HT, Hsu CH and Cheng KM (2013) An Analysis of Consumer Demand for Sports Drinks: An Application of the Kano Model. International Journal of Management 30(4): 262-270.

Cordero-Ampuero J, Darder A, Santillana J, Caloto MT and Nocea G (2012) Evaluation of Patients' and Physicians' Expectations and Attributes of Osteoarthritis Treatment using Kano Methodology. Qual Life Res 21: 13911404.

Erto P, Vanacore A and Staiano M (2011) A Service Quality Map Based on Kano's Theory of Attractive Quality. The TQM Journal 23(2): 196-215.

Fariza AN (2011) Pengembangan Model Kesuksesan Produk dengan Refined Kano. Yogyakarta: Teknik Industri Universitas Gadjah Mada.

Garibay C, Gutiérrez H and Figueroa A (2010) Evaluation of a Digital Library by Means of Quality Function Deployment (QFD) and the Kano Model. The Journal of Academic Librarianship 36(2): 125-132.

Ghorabi M, Kafashpor A and Kashani BH (2012) Identification of Customers' Satisfaction Attributes in Offset Printing Industry. Interdisciplinary Journal of Contemporary Research in Business 4(6): 468-477.

Gruber T, Lowrie A, Brodowsky GH, Reppel AE, Voss $R$ and Chowdhury IN (2012) Investigating the Influence of Professor Characteristics on Student Satisfaction and Dissatisfaction: A Comparative Study. Journal of Marketing Education 34:165-178.

Hogstrom C, Rosner M and Gustafsson A (2010) How to Create Attractive and Unique Customer Experiences an Application of Kano's Theory of Attractive Quality to Recreational Tourism. Marketing Intelligence $\mathcal{E}$ Planning 28(4): 385-402.

Hultink EJ and Robben HSJ (1995) Measuring New Product Success: The Difference 
that Time Perspective Makes. J Prod Innov Manag 12: 392-405.

Kaebernick H, Farmer LE and Mozar S (1996) Concurrent Product and Process Design, The University of New South Wales.

Kuo CM, Yuo SH and Lu CY (2014) Integration of the Kano and QFD Model in Health Food Development: Using Black Beans as Examples, Qual Quant 48: 225-242.

Kurt SD and Atrek B (2012) The Classification and Importance of E-S-Qual Atribut kualitas: An Evaluation of Online Shoppers. Managing Service Quality 22(6): 622-637.

Lai HJ and Wu HH (2011) A Case Study of Applying Kano's Model and ANOVA Technique in Evaluating Service Quality. Information Technology Journal. 10(1): 89-97.

Lajevardi M, Fakharmanesh S, Emami J and Lajevardi M (2012) An Applied Marketing Model for University Students' Satisfaction. Australian Journal of Business and Management Research 2(9): 1-12.

Lin SP, Yan, CL, Chan,YH and Sheu C (2010) Refining Kano's 'Atribut kualitasSatisfaction' Model: A Moderated Regression Approach. Int. J. Production Economics 126: 255-263.

Liu KT (2011) Exploration Convenience Store Service Quality Phenomenon in Taipei by Experiential Marketing with Kano Model. The Journal of Human Resource and Adult Learning 7(2): 175-182.

Liu MS (2013) Assessing Student Dormitory Service Quality by Integrating Kano Elaborative Mode with Quality Function Deployment Method - A Case Study in a Hospitality College in Southern Taiwan. The International
Journal of Organizational Innovation 5(3): 133-157.

Llinares C and Page AF (2011) Kano's Model in Kansei Engineering to Evaluate Subjective Real Estate Consumer Preferences. International Journal of Industrial Ergonomics 41: 233-246.

Lofgren M and Witell L (2005) Kano's Theory of Attractive Quality and Packaging. QMJ 12(3): 7-20.

Lofgren M, Witell L and Gustafsson A (2011) Theory of Attractive Quality and Life Cycles of Atribut kualitas. The TQM Journal 23(2): 235-246.

Luthfitriaputri VA (2013) Pengembangan Model Matematis untuk Value Proposition Produk berupa Barang pada Kanvas Model Bisnis. Yogyakarta: Program Studi Teknik Industri, Universitas Gadjah Mada.

Luthfitriaputri VA (2014) Pengembangan Model untuk Memprediksi Kesuksesan Bisnis Produk Berupa Barang. Yogyakarta: Program Studi Pascasarjana Teknik Industri, Universitas Gadjah Mada.

Matias-Guiu J, Caloto,MT and Nocea G (2012) Comparison of Expected Outcomes between Patients and Neurologists using Kano's Methodology in Symptomatic Migraine Treatment. Patient 5(3): 147-162.

Mikulic J and Prebezac D (2011) A Critical Review of Techniques for Classifying Atribut kualitas in The Kano Model. Managing Service Quality 21(1): 46-66.

Nugroho SS (2013) Model Matematis Value Proposition Industri Jasa pada Kanvas Model Bisnis.Yogyakarta: Program Studi Teknik Industri, Universitas Gadjah Mada.

Oh JC, Yoon SJ and Park BI (2012) A Structural Approach to Examine the Atribut kualitas of E-Shopping Malls using the Kano Model. Asia Pacific Journal 
of Marketing and Logistics 24(2): 305327.

Rezaie M, Nosratabadi HE and Fazlollahtabar H (2012) Applying Kano Model for Users' Satisfaction Assessment in E-Learning Systems: A Case Study in Iran Virtual Higher Educational Systems. International Journal of Information and Communication Technology Education 8(3): 1-12.

Shahin A (2004) Integration of FMEA and the Kano Model an Exploratory Examination. International Journal of Quality \& Kehandalan Management 21(7): 731-746.

Shahin A and Nekuie N (2011) Development of the Kano Model: A Novel Approach Based on Linear Logarithmic Transformation with a Case Study in an Air Travel Agency. Asian Journal on Quality 12(2): 176188.

Strandberg C, Wahlberg $\mathrm{O}$ and Ohman $P$ (2012) Challenges in Serving the Mass Affluent Segment: Bank Customer Perceptions of Service Quality. Managing Service Quality 22(4): 359-385.

Sukwadi R and Yang CC (2014) Determining Service Improvement Priority in a Zoological Park. Journal of Industrial Engineering and Management 7(1): 1-20.

Sukwadi R, Yang CC and Fan L (2012) Capturing Customer Value Creation Based on Service Experience - A Case Study on News Cafe. Journal of the Chinese Institute of Industrial Engineers 29(6): 383-399.

Trisna A (2013) Model Matematis Hubungan Customer Segment dan Value Proposition pada Kanvas Model Bisnis. Yogyakarta: Program Studi Teknik Industri, Universitas Gadjah Mada.
Ullah AMMS and Tamaki J (2011) Analysis of Kano-Model-Based Customer Needs for Product Development. Systems Engineering 14(2): 154-172.

Wang T and Ji P (2010) Understanding Customer Needs through Quantitative Analysis of Kano's Model. International Journal of Quality $\mathcal{E}$ Kehandalan Management 27(2): 173184.

Xu Q, Jiao RJ, Yang X, Helander M, Jiao RJ, Khalid HM and Opperud A (2009) An Analytical Kano Model for Customer Need Analysis. Design Studies 30: 87-110.

Yadav HC, Jain R, Singh AR and Mishra PK (2013) Aesthetical Design of a Car Profile: A Kano Model-Based Hybrid Approach. Int J Adv Manuf Technol 67: 2137-2155.

Yang CC (2005) The Refined Kano's Model and Its Application. Total Quality Management 16(10): 1127-1137.

Yang CC and Yang KJ (2011) An Integrated Model of Value Creation Based on the Refined Kano's Model and the Blue Ocean Strategy. Total Quality Management 22(9): 925-940.

Yang CC Jou YT and Cheng LY (2011) Using Integrated Quality Assessment for Hotel Service Quality. Qual Quant 45: 349-364.

Yooyen A and Leerattanakorn N (2011) The Demand for Hygienic Pork and Organic Pork Product in Chiang Mai, Thailand. International Journal of Arts \& Sciences 4(26): 95-118.

Yu YC (2013) Kinerja of Food and Beverage Department Promoted through Promotion Plan. International Journal of Advancements in Computing Techno$\log y$ 5(6): 160-166. 